\title{
GLOBAL PATENT LAW HARMONIZATION: BENEFITS AND IMPLEMENTATION
}

\section{THE IMPORTANCE OF Globally HaRMONIZED PATENT LAW}

The international intellectual property arena, as it exists today, is a segmented potpourri of national patent systems that serve to inhibit the efficient and economical resolution of international patent issues. As the distances and differences between countries become smaller through emerging technology, the need for a truly global patent system becomes imperative as opposed to the fiercely nationalistic systems of today. ${ }^{1}$

There have been many discussions on global patent law harmonization throughout the past one hundred years. ${ }^{2}$ Despite these efforts, global patent law harmonization has yet to be achieved. ${ }^{3}$ However, it is still important that the world continue to make an effort to globally harmonize patent law because the protection of intellectual property rights worldwide is critical to the international trading of goods and services as at some level nearly all legitimately traded goods and services operate under patent, copyright, or trademark protection. ${ }^{4}$

Global harmonization of patent law is necessary for many reasons. ${ }^{5}$ One main reason is that because nations are transforming from industrial-based economies to information-based economies, worldwide uniform protection of intellectual property deeply affects trade issues. ${ }^{6}$ Another main reason is that patent law harmonization would evenly spread the administrative burden and redundancy present in prosecuting international patent applications among participating nations. ${ }^{7}$ Consequently, uniform patent laws would reduce the cost of prosecuting an international patent. ${ }^{8}$

This Note will explore several aspects of international patent law while analyzing the benefits and implementation of a globally harmonized system

1. Anneliese M. Seifert, Will the United States Take the Plunge into Global Patent Law Harmonization? A Discussion of the United States' Past, Present, and Future Harmonization Efforts, 6 MARQ. INTELL. PROP. L. REv. 173, 173 (2002).

2. See id.

3. See id.

4. See John E. Guist, Noncompliance With TRIPs by Developed and Developing Countries: Is TRIPs Working?, 8 IND. INT'L \& COMP. L. REV. 69, 69 (1997).

5. See Kevin Cuenot, Perilous Potholes in the Path Toward Patent Law Harmonization, 11 J. LAW. \& PUB. POL'Y 101, 101 (1999).

6. See id.

7. See id.

8. See id. 
of patent law. Part II of this Note will discuss the basics of patent law. Part III will discuss important, multinational agreements in the history of international patent law. Part IV will discuss aspects of current patent systems in the world and how some of these systems function as obstacles for globalizing patent law. Part $\mathrm{V}$ will discuss the benefits of globally harmonizing patent law. ${ }^{9}$ Part VI will provide two different types of globally harmonized patent law systems and discuss their implementation and aspects. Finally, Part VII will conclude this Note with a discussion of what the future may hold for the global harmonization of patent law.

\section{The Basics Of Patent Law}

The patent system is the primary mechanism for extending property rights to new technology. ${ }^{10}$ "A patent is a government grant of a monopoly on an invention for a term of years, after which, the technology enters the public domain." Patents protect the fundamental elements of inventions and emerging technology. ${ }^{12}$ Subject matter protected by patents can range from products, machines, compositions, or processes. ${ }^{13}$ The patent describes the invention and gives the owner the right to exclude others from producing, using, or selling the invention without consent. ${ }^{14}$ "In order for an invention to be patentable, it must possess a minimum degree of non-obviousness and novelty."15

Domestic patent laws have dual functions: (1) they stimulate scientific research by rewarding inventors with limited monopolies on their inventions; and (2) they foster economic benefits for the inventor's nation. ${ }^{16}$ Without some type of international protection beyond the domestic protection, the benefits of patents would be frustrated, and a nation's economy and trade ultimately would suffer. ${ }^{17}$

9. When discussing the benefits of patent law, three perspectives will be used. The United States will be one perspective. The European community will be another perspective discussed. The third and final will be the perspective of developing nations.

10. See Donald S. Chisum, The Harmonization of International Patent Law, 26 J. MARSHALl L. REV. 437, 437 (1993).

11. Isaac Hasson, Domestic Implementation of International Obligations: The Quest for World Patent Law Harmonization, 25 B.C. INT' L \& COMP. L. REV. 373, 375 (2002).

12. See id.

13. See id.

14. See id.

15. Id.

16. See id.

17. See Hasson, supra note 11 , at 375 . 


\section{HistoriCAL INTERNATIONAL PATENT LAW}

\section{A. The Paris Convention for the Protection of Industrial Property ${ }^{18}$}

The need for international protection of intellectual property ${ }^{19}$ was realized as early as $1873 .{ }^{20}$ Many inventors kept their inventions secret due to the fear of having their ideas stolen or exploited. ${ }^{21}$ The Paris Convention for the Protection of Industrial Property (Paris Convention) was entered into in 1883 to reduce these fears. ${ }^{22}$ This treaty was the precursor of all modern-day multinational protection for intellectual property. ${ }^{23}$

The Paris Convention established several fundamental principles. ${ }^{24}$ These fundamental principles of "national treatment,"25 "right of priority,"26

18. Paris Convention for the Protection of Industrial Property, Mar. 20, 1883, 21 U.S.T. 1583 [hereinafter Paris Convention].

19. The Paris Convention covers industrial property, namely, patents, trademarks, trade names, industrial designs, and unfair competition. Gerald J. Mossinghoff \& Vivian S. Kuo, World Patent System Circa 20XX A.D., 38 IDEA 529, 532 (1998).

20. See Cuenot, supra note 5, at 103.

21. See id. at 104.

22. See id. Originally, fourteen nations signed the treaty. See id. Before this treaty, inventors had to submit patent applications simultaneously in all the countries where protection was desired. See Mossinghoff \& Kuo, supra note 19, at 532. "Failure to do so could preclude patent protection in all but one country, with the first application destroying the 'novelty' of the invention for subsequent applications." Id. "In addition, inventors had to comply with often radically different procedural and substantive requirements to obtain patent protection." $I d$. "This lack of adequate protection for foreign inventors became apparent during the international exhibition of inventions in 1873 in Vienna; inventors refused to participate for fear of losing patentability of their inventions." Id.

23. See Mossinghoff \& Kuo, supra note 19, 532.

24. See id.

25. Article 2(1) of the Paris Convention contains the following:

Nationals of any country of the Union shall, as regards the protection of industrial property, enjoy in all the other countries of the Union the advantages that their respective laws now grant, or may hereafter grant, to nationals; all without prejudice to the rights specially provided for by this Convention. Consequently, they shall have the same protection as the latter, and the same legal remedy against any infringement of their rights, provided that the conditions and formalities imposed upon nationals are complied with.

Paris Convention, supra note 18, art. 2(1).

26. The relevant sections of the Paris Convention are as follows:

Any person who has duly filed an application for a patent, or for the registration of a utility model, or of an industrial design, or of a trademark, in one of the countries of the Union, or his successor in title, shall enjoy, for the purpose of filing in the other countries, a right of priority during the periods hereinafter fixed.

Id. art. 4(A)(1). "The periods of priority referred to above shall be twelve months for patents ...." Id. art. $4(\mathrm{C})(1)$. 
and "special agreements" 27 have been incorporated in all subsequent multinational patent agreements. ${ }^{28}$ "National treatment" requires member states to accord nationals of other member states the same advantages under their domestic patent laws as they accord to their nationals. ${ }^{29}$ "Right of priority" entitles a patent applicant of one member country to a period of twelve months after the initial patent application to apply for protection..$^{30}$ Member nations can also enter into "special agreements," forging stronger cooperation in patent protection. ${ }^{31}$ "These 'special agreements' may be bilateral or multilateral, but they must not contravene the other provisions of the Paris Convention." 32 This is an important part of the treaty because all subsequent multinational and regional patent protection schemes are derived from this provision and are regarded as "special agreements." ${ }^{33}$

Although the Paris Convention eliminated some major roadblocks, ${ }^{34}$ it is rather rudimentary in providing inventors with any uniform standard of substantive patent rights. ${ }^{35}$ In short, the Paris Convention provides an important entry for inventors to journey down the path of multinational patent protection..$^{36}$

27. Article 19 of the Paris convention provides: "It is understood that the countries of the Union reserve the right to make separately between themselves special agreements for the protection of industrial property, in so far as these agreements do not contravene the provisions of this Convention." Id. art. 19.

28. See Mossinghoff \& Kuo, supra note 19, at 534.

29. See id. at 532. Practically speaking, this means a national of one member country enjoys the same rights in every member country of the Paris Convention as nationals of the country where the patent application is filed. See id. at 533. "However, nationals seeking patent protection in a member country must comply with the domestic laws of the member country from which they seek patent protection." Id. at 534.

30. See id. "Within this one year period, nationals of member countries are further entitled to tie subsequent applications back to the earliest filing date." Id. "This provision offers great practical advantages to applicants desiring multinational patent protection." Mossinghoff \& Kuo, supra note 19, at 534. "It avoids intervening prior art which would otherwise prevent a patent and serves to overcome the novelty requirement, and it allows applicants time to assess the economic viability of their inventions and determine where they desire patent protection." Id.

31. See id. at 534.

32. Id.

33. See id. "By structuring a multinational patent protection system under this provision of the Paris Convention, these regional and multinational patent efforts must, at the minimum, provide for national treatment and the right of priority." Id.

34. See Mossinghoff \& Kuo, supra note 19, at 534. The roadblocks were both preclusion of cross-border patent protection and inventors being unable to exploit their inventions internationally. See id.

35. See id. "The Paris Convention does not define patentable subject matter, prescribe patent term, provide meaningful limitations to compulsory licenses or guide patent claim interpretation and enforcement. It relegates those substantive issues to the discretion of each member country." Id.

36. See id. 


\section{B. The Patent Cooperation Treaty ("PCT") 37}

"Whereas the Paris Convention dealt with substantive issues of patent protection, the ... [PCT] deals with procedures to obtain international patent protection." 38 The United States took the lead role in the late 1960s in creating a new multilateral patent treaty to minimize duplicative patent application and examinations worldwide. ${ }^{39}$ The PCT took effect on January $1,1978 .{ }^{40}$ The PCT constituted an important step towards rationalizing the filing of patent applications worldwide. "Stripped down to its essentials, ${ }^{42}$ the PCT enables an inventor to prosecute a single international patent application to obtain patent protection in multiple regions." 43

Although the PCT did not focus directly on the substance of patent law,

37. Patent Cooperation Treaty, June 19, 1970, 28 U.S.T. 7645 [hereinafter PCT]. A list of the members of the PCT is located on the website of the World Intellectual Property Organization (WIPO). PCT member nations, available at http://www.wipo.org/ treaties/documents/english/pdf/m-pct.pdf (last visited Jan. 21, 2003).

38. Cuenot, supra note 5, at 106.

39. See Mossinghoff \& Kuo, supra note 19, at 535. This took an economic burden off of inventors who no longer had to file patent applications in multiple countries. See Cuenot, supra note 5, at 106.

40. See Cuenot, supra note 5, at 106.

41. See Mossinghoff \&Kuo, supra note 19, at 535.

42. The actual PCT process is carried out as follows:

The first step requires the applicant to file an international application in one of several designated national patent offices. The PCT permits applicants to designate as many of the contracting states as desired during this filing process and delays, for as long as thirty months, the need for multiple filings in the individual states. The PCT also extends the inventor's national state entry under the Paris Convention from twelve to twenty months. Once an international application is received by an appropriate receiving national patent office, the office examines the application as to formal requirements, and, if it is designated as an international Searching Authority, conducts a novelty search and completes an international Search Report. This report indicates the classification of the invention, the technical fields searched and citations to the prior art. In almost $80 \%$ of PCT applications, applicants also request an International Preliminary Examination $\mathrm{B}$ a non-binding opinion on whether the invention appears to be novel, to involve an inventive step (to be non-obvious), and to be industrially applicable. The goal is to remove some of the duplicative efforts expended by examiners from various countries in reviewing formalities and conducting prior art searches. By allowing one office to handle some of the pre-filing and postfiling requirements, examiners from other national offices are able to focus on the substantive applications of their domestic laws. The next step of the PCT process is the national phase. Once an applicant receives the International Search Report and an International Preliminary Examination, if requested, for his or her invention, the applicant may enter the national stage in the various patent offices where protection is desired. The patent officials at those offices examine the application in light of the PCT results, but based entirely on their own national patent requirements and decide whether to grant or deny a patent.

Id. at 535-36.

43. Cuenot, supra note 5 , at 107. 
it indirectly provided substantial impact. ${ }^{44}$ Also, the PCT rationalized the patent application process concerning filing, searching, and preliminary examination, it does not result in a globally harmonized patent system, which would result in one international patent. ${ }^{45}$

\section{The Failed World Intellectual Property Organization ${ }^{46}$ (WIPO) Harmo- nization Discussions}

44. See Mossinghoff \& Kuo, supra note 19, at 536. "The accession process for member states requires minimum patent standards and regulations." Id. "Many countries augmented their national patent standards to become signatory states." Id. "Although the PCT has been criticized for its extensive procedural requirements and the lack full faith and credit accorded to International Search Reports and International Preliminary Examinations, the number of member states and applications submitted to the PCT have continued to grow." Id.

45. See Cuenot, supra note 5, at 107.

46. The WIPO offers a description of itself at its website:

The World Intellectual Property Organization (WIPO) is an international organization dedicated to promoting the use and protection of works of the human spirit. These works - intellectual property - are expanding the bounds of science and technology and enriching the world of the arts. Through its work, WIPO plays an important role in enhancing the quality and enjoyment of life, as well as creating real wealth for nations. With headquarters in Geneva, Switzerland, WIPO is one of the 16 specialized agencies of the United Nations system of organizations. It administers 23 international treaties dealing with different aspects of intellectual property protection. The Organization counts 179 nations as member states.

WIPO, About WIPO, at http://www.wipo.org/about-wipo/en/ (last visited Jan. 21, 2003). The WIPO also discusses the challenges associated with globalization:

While a decade ago the term 'international' was most commonly used to describe the relations between nations, the current trend is to use 'globalization.' This change in terminology denotes a fundamental shift in the manner in which the world interacts. The world is witnessing a transformation of a model based on the interaction between fragmented territorial components, 'nations,' to one of seamless interaction across the globe.

WIPO, Challenges: Globalization, at http:/www.wipo.org/about-wipo/en/ (last visited Nov. 25, 2002).

One element that is both a cause and effect of globalization is the creation of a legal framework that is geared to facilitate it. It is evident that global commerce is greatly hampered by a patchwork of inconsistent regulations across the different national territories in which it is conducted. Increased harmonization of the various legal disciplines that come into play on the global marketplace is therefore an indispensable ingredient of any policy agenda geared towards globalization. This need is felt throughout the legal system, including in particular the area of intellectual property law, because of the ever-growing importance of this discipline for those industries driving the modern economy, such as the information technology, entertainment and biotechnology industries. Intellectual property rights and the mechanisms to enforce them are fundamentally territorial in nature. The scope of the rights created in each country is determined by that country, and the effect of these rights, as well as their protection, are, in principle, defined by and confined to the territory of the nation State. As the organization competent and responsible for the formulation of intellectual property policy at the international level, the first challenge for WIPO will be to adjust the existing intellectual property system in order to make it function harmoniously in a global world.

ld. at 6-7. 
In 1985, the WIPO began discussions regarding global harmonization of patent laws. ${ }^{47}$ "This treaty would have changed the United States patent system from a first-to-invent to a first-to-file system, ${ }^{48}$ created a prior user defense, called for publishing applications, and based the patent term on the filing date rather than the date of issuance." ${ }^{, 9}$

In exchange for these concessions, the United States asked for (1) a grace period for disclosures and removal of the absolute novelty principle $;^{50}(2)$ an international doctrine of equivalents; ${ }^{51}$ (3) the removal of the pre-grant opposition procedure; and (4) the ability to file applications in English, with the English application to serve as the official copy in cases of translation errors. ${ }^{52}$

The United States also requested a delay and in 1994 declared that it would not switch from a first-to-invent system to a first-to-file system. ${ }^{53}$ "As a result, the conference ended because the first-to-file concession was the cornerstone of all of the negotiations." 54

\section{Trade-Related Aspects of Intellectual Property Rights ${ }^{55}$ (TRIPS Agree- ment)}

At the conclusion of World War II, nations began to recognize the desirability of international trade agreements. ${ }^{56}$ This began the General

47. See Seifert, supra note 1 , at 184 . These discussions took place in Geneva, Switzerland. See id.

48. See infra Part IV.

49. Seifert, supra note 1 , at 184.

50. The one-year grace period is unique to the United States, whereas most countries require "absolute novelty," in other words, if information relating to the function of a patent occurs in any type of publication prior to the application for patent, then the inventor loses his patent rights. See Donald R. Palladino, The Publication Bar: How Disclosing an Invention to Others Can Jeopardize Potential Patent Rights, 37 DUQ. L. REV. 353, 354 n.8 (1993). The United States however, allows a unique, one-year grace period after publication before an inventor loses his patent rights. See 35 U.S.C. $\$ 102$ (a)-(b) (2002).

51. See infra Part V(A).

52. Seifert, supra note 1 , at 184.

53. See id.

54. Id. "The inauguration of the Clinton administration is cited as the reason that the United States pulled out of negotiations." Id. "Previous successful negotiations occurred during the Reagan and Bush administrations." Id. at 184-85.

55. General Agreement on Tariffs And Trade - Multilateral Trade Negotiations: Agreement On Trade-Related Aspects Of Intellectual Property Rights, January 1994, 33 I.L.M. 81 [hereinafter TRIPS].

56. See Hasson, supra note 11 , at 375. 
Agreement on Tariffs and Trade $^{57}$ (GATT) negotiations. ${ }^{58}$ The TRIPS Agreement was created in 1994 at the Uruguay Round, ${ }^{59}$ the most recent of

57. The history and rationale of the GATT is as follows:

The WTO's predecessor, the GATT, was established on a provisional basis after the Second World War in the wake of other new multilateral institutions dedicated to international economic cooperation - notably the 'Bretton Woods' institutions now known as the World Bank and the International Monetary Fund. The original 23 GATT countries were among over 50 which agreed a draft Charter for an International Trade Organization (ITO) - a new specialized agency of the United Nations. The Charter was intended to provide not only world trade disciplines but also contained rules relating to employment, commodity agreements, restrictive business practices, international investment and services. In an effort to give an early boost to trade liberalization after the Second World War - and to begin to correct the large overhang of protectionist measures which remained in place from the early 1930 s - tariff negotiations were opened among the 23 founding GATT 'contracting parties' in 1946. This first round of negotiations resulted in 45,000 tariff concessions affecting $\$ 10$ billion - or about one-fifth - of world trade. It was also agreed that the value of these concessions should be protected by early - and largely 'provisional' - acceptance of some of the trade rules in the draft ITO Charter. The tariff concessions and rules together became known as the General Agreement on Tariffs and Trade and entered into force in January 1948. Although the ITO Charter was finally agreed at a UN Conference on Trade and Employment in Havana in March 1948 ratification in national legislatures proved impossible in some cases. When the United States' government announced, in 1950, that it would not seek Congressional ratification of the Havana Charter, the ITO was effectively dead. Despite its provisional nature, the GATT remained the only multilateral instrument governing international trade from 1948 until the establishment of the WTO. Although, in its 47 years, the basic legal text of the GATT remained much as it was in 1948, there were additions in the form of plurilateral - voluntary membership agreements and continual efforts to reduce tariffs. Much of this was achieved through a series of 'trade rounds.'

E. Kwan Choi, The Roots of the WTO: A Brief History of the GATT, at http://www.econ.iastate.edu /classes/econ355/choi /wtoroots.htm (last visited Jan. 21, 2003).

58. See Hasson, supra note 11, at 376.

59. "The Uruguay Round also established the World Trade Organization (WTO) to oversee GATT and [the TRIPS Agreement]." Id. "Developed signatories support the WTO because it promotes enhanced enforcement of rights in developing countries by undertaking a proactive trade surveillance role." Id. The history of the WTO is provided on its website:

The past 50 years have seen an exceptional growth in world trade. Merchandise exports grew on average by $6 \%$ annually. Total trade in 2000 was 22 -times the level of 1950. GATT and the WTO have helped to create a strong and prosperous trading system contributing to unprecedented growth. The system was developed through a series of trade negotiations, or rounds, held under GATT. The first rounds dealt mainly with tariff reductions but later negotiations included other areas such as anti-dumping and non-tariff measures. The last round -the 1986-94 Uruguay Round -led to the WTO creation.

The negotiations did not end there. Some continued after the end of the Uruguay Round. In February 1997 agreement was reached on telecommunications services, with 69 governments agreeing to wide-ranging liberalization measures that went beyond those agreed in the Uruguay Round. In the same year 40 governments successfully concluded negotiations for tariff-free trade in information technology products, and 70 members concluded a financial services deal covering more than $95 \%$ of trade in banking, insurance, securities and 
several rounds of GATT negotiations. ${ }^{60}$ The TRIPS Agreement primarily resulted from the concern among developed countries that lobbied for protection against international piracy of intellectual property rights. ${ }^{61}$

The TRIPS Agreement formally recognizes the "need to "promote effective and appropriate means for the enforcement' of intellectual property rights, and provides for 'expeditious procedures for the multilateral prevention and settlement of disputes' relating to private intellectual property rights."

financial information.

In 2000, new talks started on agriculture and services. These have now been incorporated into a broader agenda launched at the fourth WTO Ministerial Conference in Doha, Qatar, in November 2001. The agenda adds negotiations and other work on non-agricultural tariffs, trade and environment, WTO rules such as anti-dumping and subsidies, investment, competition policy, trade facilitation, transparency in government procurement, intellectual property, and a range of issues raised by developing countries as difficulties they face in implementing the present WTO agreements.

WTO, The WTO In Brief: Part 1 The multilateral trading system past, present and future, at http://www.wto.org/english/thewto_e/whatis_e/inbrief_e/inbr01_e.htm (last visited Nov. 25, 2002). The organization of the WTO is also described on the WTO website:

The World Trade Organization came into being in 1995. One of the youngest of the international organizations, the WTO is the successor to the General Agreement on Tariffs and Trade (GATT) established in the wake of the Second World War.

WTO, The WTO In Brief: Part 2 - The organization, at http://www.wto.org/english/thewto_e/ whatis_e/inbrief_e/inbr01_e.htm (last visited Nov. 25, 2002).

The WTO overriding objective is to help trade flow smoothly, freely, fairly and predictably. It does this by: [a]dministering trade agreements; [a]cting as a forum for trade negotiations; [s]ettling trade disputes; [r]eviewing national trade policies; [a]ssisting developing countries in trade policy issues, through technical assistance and training programs; [and] [c]ooperating with other international organizations. The WTO has more than 140 members, accounting for over $97 \%$ of world trade. Around 30 others are negotiating membership.

Decisions are made by the entire membership. This is typically by consensus. A majority vote is also possible but it has never been used in the WTO, and was extremely rare under the WTO predecessor, GATT. The WTO agreements have been ratified in all members parliaments. The WTO top level decision-making body is the Ministerial Conference which meets at least once every two years. Below this is the General Council (normally ambassadors and heads of delegation in Geneva, but sometimes officials sent from members capitals) which meets several times a year in the Geneva headquarters. The General Council also meets as the Trade Policy Review Body and the Dispute Settlement Body. At the next level, the Goods Council, Services Council and Intellectual Property (TRIPS) Council report to the General Council. Numerous specialized committees, working groups and working parties deal with the individual agreements and other areas such as the environment, development, membership applications and regional trade agreements.

WTO, The WTO In Brief: Part 2 The organization, at http://www.wto.org/english/thewto_e/ whatis_e/inbrief_e/inbr02_e.htm (last visited Nov. 25, 2002).

60. See Hasson, supra note 11, at 376. The TRIPS Agreement was signed after the failure of the WIPO harmonization discussion. See id.; see supra Part II(C).

61. See Hasson, supra note 11, at 376.

62. Id. 
The practical effect on patent systems has actually been the some harmonization of the world's patent laws. ${ }^{63}$ The resulting harmonization comes from requirements of the TRIPS Agreement that all signatories enact domestic legislation to implement the minimum levels of patent protection provided by the TRIPS Agreement. ${ }^{64}$

The TRIPS Agreement also establishes the criteria for patentable subject matter. ${ }^{65}$ A patent must be made available for any invention, product, or process, regardless of its field of technology. ${ }^{66}$ Also, existing guidelines define subject matter that may not be patentable. ${ }^{67}$ Furthermore, the TRIPS Agreement provides that all rights under it are to apply to all of its members, thereby disposing of the past use of reciprocity. ${ }^{68}$ Moreover, the TRIPS Agreement applies the most favored nation principle in affording patent protection, where with few exceptions any advantage, favor, privilege, or immunity granted by an Agreement member to the nationals of any other country must be granted immediately and unconditionally to the nationals of all other members. ${ }^{69}$

It also establishes the basic rights that must be accorded to each Agreement member's nationals." "The major provisions of the TRIPS legislation changed the patent term from seventeen years from the date of issuance, to twenty years from the date of filing and implemented a provisional application." 71 A maximum five-year term extension could be obtained for delays attributed to successful appeals, secrecy orders, and interferences. ${ }^{72}$

63. See id.

64. See id. "Thus, developed and non-developed signatories alike must adhere to an international baseline for patent protection and ensure effective, expeditious, and impartial application of patent rights." Id.

65. See id. at 377 . Article 27 provides that, "[a patent] shall be available for any invention ... in all fields of technology, provided that they are new, involve an inventive step, and are capable of industrial application." TRIPS, supra note 55, art. 27.

66. See Hasson, supra note 11, at 377 . "In addition, Article 27 sets forth clear guidelines for subject matter that may not be patentable." Id.

67. See id.; see also TRIPS, supra note 55, art. 27. However exceptions do exist, which includes: inventions necessary to protect "ordre public" (emphasis added) or morality; diagnostic, therapeutic and surgical methods for the treatment of humans or animals; and naturally existing plants, animals, and essentially biological processes for the production of plants or animals. See Hasson, supra note 11, at 377.

68. See Hasson, supra note 11 , at 377 . This is different than the national treatment clauses, such as included in the Paris Convention, whereby each signatory is compelled to accord to the nationals of other member countries no less favorable than each signatory country would treat its own nationals. See id.; see infra Part III(A).

69. See Hasson, supra note 11, at 377.

70. See id.

71. Seifert, supra note 1, at 185 . "Because the patent term is measured from the date of filing, expedient prosecution is crucial." Id.

72. See id. "Additionally, TRIPS put an end to the United States' practice of skirting the Paris Convention and discriminating as to place of invention." Id.; see infra Part III(A). For a definition of "interferences" see infra note 127. 
Even with the advantages of the change in patent term, ${ }^{73}$ there has been opposition to the twenty-year patent term. ${ }^{74}$ The TRIPS Agreement also provides that a patent grants an inventor the right to prohibit third parties from making, using, selling, offering to sell, or importing the subject matter of a patent. $^{75}$

The TRIPS Agreement also addresses developing countries by providing for a delayed schedule for its entry into force in developing countries. "The leniency expressed in these articles allows a developing country an opportunity to slowly adapt and further expand its economy prior to compliance."77 These provisions relating to developing countries represent the concessions made by developed nations in order to acquire the consent of the underdeveloped members of the TRIPS Agreement. ${ }^{78}$ Initially developing Agreement members rightfully contended that stringent protection of intellectual property would further impede their development, because they believed that the Agreement would result in a loss of their sovereignty and increased dependence on more developed Agreement members." "However, many such nations ultimately assented, believing that the potential gains from freer trade were 'irresistible." "80

To be truly effective, enforcement provisions were considered necessary. ${ }^{81}$ The TRIPS Agreement requires that all members to have

73. See Seifert, supra note 1, at 186. Three advantages exist: "First, patents would receive a longer term because applications would only take an average of nineteen months to issue." Id. "Second, basing the term from the date of filing would discourage 'submarine patents." Id. "Third, dates used to gain priority, such as a foreign filing date, would not be used when computing the patent term." Id. The term "submarining" refers to the practice of a party delaying issuance of a patent until the industry has caught up with the technology in order to gain larger royalties. See Dana Rohrabacher, Pennies for Thought: How GATT Fast Track Harms American Patent Applicants, 11 ST. JOHN's J. LEGAL COMMENT 49I, 497 (1996).

74. See Seifert, supra note 1, at 186 . "The patent term is measured from the date of filing." Id. "Because the length of prosecution can vary, uncertainty in the length of the patent term creates difficulty in attracting licensees and capital." Id. "Also, many inequalities are created when one patent lasts longer than another." Id. "Furthermore, patents in complex areas such as biotechnology take much longer than nineteen months to issue." Id. "Critics also state that TRIPS should have provided the option of either a seventeen-year term from the date of issuance, or a twenty-year term from the date of filing." Id.

75. See Seifert, supra note 1, at 186; see also TRIPS, supra note 55, art. 28.

76. See Hasson, supra note 11 , at 378 . Under the TRIPS Agreement, developing Agreement members were entitled to delay implementation of the TRIPS Agreement for four years. See id.; see also TRIPS, supra note 55, art. 65. Also, "least developed" Agreement members were allowed to delay implementation for ten years. See Hasson, supra note 11, at 378; see also TRIPS, supra note 55, art. 65.

77. Hasson, supra note 11 , at 378 .

78. See id.

79. See id.

80. Id.

81. See id. 
enforcement procedures available under their laws. ${ }^{82}$ Other procedural safeguards exist in the Agreement as well. ${ }^{83}$ Also, the TRIPS Agreement formally recognizes the need for "procedures for multilateral prevention and settlement of disputes." 84

"Thus, the TRIPS Agreement laid the foundation for the international protection of patents. ${ }^{, 85}$ All members were required to join the WTO and were also compelled to adapt their domestic patent laws, pursuant to the Agreement, in exchange for mutual protection of intellectual property. ${ }^{86}$

\section{CuRrent Patent Systems ANd ObstaCles to HaRmonization}

"[I]nherently competing interests exist on both the national and international levels for providing patent protection." ${ }^{87}$ On the national level, a conflict exists between the rights of the inventor to his invention versus the public interest of promoting technological and economic development. ${ }^{88}$ On the international level, conflicts exist arising from the interests a sovereign nation has in providing national patent protection versus the interests of the international community in unrestricted trade and technology transfers. ${ }^{89}$

Both patent protection and the patent grant itself derive from the sovereign as incidents of national law. ${ }^{90}$ The national government seeks to

82. See id. Article 41 provides that each Agreement member "shall ensure that enforcement procedures ... are available under [domestic] laws so as to permit effective" and expeditious remedies against any act of patent infringement. See TRIPS, supra note 55, art. 41.

83. See Hasson, supra note 11, at 378. "Under [the] TRIP[S] [Agreement], all patent infringement actions must be: (1) decided on the merits; (2) in writing; and (3) reasoned only upon evidence after each party thereto is afforded an opportunity to be heard." $I d$. at 379 . "In addition, a party is entitled to judicial review of administrative decisions." Id. "In providing remedies for a contesting state, judicial authorities are permitted to award judgment in the form of an injunction, damages, and even an order that the infringing goods be destroyed without compensation." Id.

84. Id. "For example, [the] TRIP[S] [Agreement] provides a suitable binding dispute resolution procedure that former international intellectual property conventions lacked." Id. "Under Article 64, the dispute settlement procedures set forth in GATT are made applicable to patent dispute resolution and are to be monitored by the Council for [the] TRIP[S] [Agreement]." Hasson, supra note 11, at 379. "Furthermore, all signatories are required to abide by the decisions of the Dispute Settlement Body of the WTO." Id. "The Dispute Settlement Body, consisting of a panel of three Members to make initial decisions and another three Member appellate panel, possesses the authority to make findings or recommendations, and may authorize a country to take reprisals against an erring WTO Member." Id.

85. Id.

86. Id. "Some of these required changes ... compelled the United States to expand the scope of patent infringement actions, permit consideration of evidence of inventive activity abroad in patent prosecution, and expand the term of a patent to twenty years." Id. at 379-80.

87. Anthony Sabatelli \& J.C. Rasser, Impediments to Global Patent Law Harmonization, 22 N. KY. L. REV. 579,584 (1995).

88. See id. at 584.

89. See id.

90. Id. 
control its patent system because it gives the government control over technological and economic developments for its own country. ${ }^{91}$ Also, nationalistic and protectionist tendencies resist pressures for change from outside the national borders. ${ }^{92}$ world. ${ }^{93}$

Goods and technology constantly flow across national borders in today's

The international impact of patents is ever increasing for three primary reasons: (1) commerce in intellectual property has become an even greater component of trade between nations; (2) world commerce has become ever more interdependent, thus establishing a need for international cooperation; and (3) piracy of intellectual property is ever increasing, particularly in the Third World, and underscores the increasing conflicts of the rights of intellectual property owners in the developed world with the economic goals of the developing world. ${ }^{94}$

However, with increasing world trade and multinational corporation growth, the problem exists of obtaining uniform patent protection that extends beyond national borders, namely international patent protection. ${ }^{95}$ "This need for international patent protection is the primary impetus in the quest for patent law harmonization., 96 "For patent harmonization to be truly effective, it must encompass a number of areas, including the following: a uniform definition of patentable subject matter; uniform application and filing procedures; uniform examination and grant procedures; and uniform interpretation, remedies, and enforcement." ${ }^{97}$ Enforceable national treaties must address all of these aspects of patent harmonization. ${ }^{98}$

One major problem of a national patent grant is that it is only valid and enforceable within the granting, territorial nation. ${ }^{99}$ Without an international treaty, a nation is powerless to enforce a patent beyond its national borders. ${ }^{100}$ "However, there have been unilateral attempts to achieve some extraterritorial control over patent enforcement." ${ }^{101}$ For example, in the United States,

91. See id.

92. See id.

93. See Sabatelli \& Rasser, supra note 87, at 584.

94. Id. at 585.

95. See id.

96. Id.

97. Id.

98. Id.

99. See Sabatelli \& Rasser, supra note 87, at 585.

100. See id.

101. Id. 
changes in the U.S. Code were enacted ${ }^{102}$ in response to the U.S. Supreme Court's decision in Deepsouth Packing Company v. Laitram Corporation, ${ }^{103}$ which held that there is no patent infringement if all the parts of an accusing device are manufactured domestically but the final construction occurs abroad. ${ }^{104}$ The United States has attempted to exert effective patent enforcement extraterritorially with these code provisions. ${ }^{105}$ "However, these attempts by the United States to achieve extraterritorial control and enforcement of intellectual property rights have been viewed as trade barriers by the international community."106

Tension between national patent rights and international trade issues and technology transfer issues is also caused by the many differences among the

102. Specifically, the sections enacted were 35 U.S.C. $\$ 271$ (f) and (g). Part (f) requires:

(1) Whoever without authority supplies or causes to be supplied in or from the United States all or a substantial portion of the components of a patented invention, where such components are uncombined in whole or in part, in such manner as to actively induce the combination of such components outside of the United States in a manner that would infringe the patent if such combination occurred within the United States, shall be liable as an infringer.

(2) Whoever without authority supplies or causes to be supplied in or from the United States any component of a patented invention that is especially made or especially adapted for use in the invention and not a staple article or commodity of commerce suitable for substantial noninfringing use, where such component is uncombined in whole or in part, knowing that such component is so made or adapted and intending that such component will be combined outside of the United States in a manner that would infringe the patent if such combination occurred within the United States, shall be liable as an infringer.

35 U.S.C. \& 271(f) (2002). Part (g) requires:

Whoever without authority imports into the United States or offers to sell, sells, or uses within the United States a product which is made by a process patented in the United States shall be liable as an infringer, if the importation, offer to sell, sale, or use of the product occurs during the term of such process patent. In an action for infringement of a process patent, no remedy may be granted for infringement on account of the noncommercial use or retail sale of a product unless there is no adequate remedy under this title for infringement on account of the importation or other use, offer to sell, or sale of that product. A product which is made by a patented process will, for purposes of this title, not be considered to be so made after --

(1) it is materially changed by subsequent processes; or

(2) it becomes a trivial and nonessential component of another product.

35 U.S.C. \$ 271 (g) (2002).

103. Deepsouth Packing v. Laitram Corp., 406 U.S. 518 (1972).

104. See Sabatelli \& Rasser, supra note 87, at 585.

105. See id. "For example, section 271(f) prohibits United States-based entities from exporting offending components of a patented invention with the object of causing an infringement outside the United States." Id. A product importation that has been made by the unauthorized use of a process patented in the United States is prohibited under 35 U.S.C. section $271(\mathrm{~g})$. See id. Furthermore, the United States has other trade laws that seek to place economic pressure on those countries which have either inadequate intellectual property laws or inadequately enforced them. See id.

106. Id. 
patent laws of the countries of the world. ${ }^{107}$ Comparing the United States patent system with the rest of the world exemplifies inconsistencies in patent laws from country to country. ${ }^{108}$ For example, what constitutes patentable subject matter varies among nations. ${ }^{109}$ Patent protection in the United States is extended to any new and useful process, machine, manufacture, or composition of matter, or any new and useful improvement. ${ }^{110}$ This protection has been extended to cover computer programs when entwined with a patentable process, genetically engineered non-human organisms and therapeutic methods of treating humans. ${ }^{11}$ "However, many other countries of the world, both developed and developing, do not provide such protection." 112

"Another major issue is the first-to-file controversy."113 The United States awards patents to the first-to-invent ${ }^{114}$ as opposed to the first-to-file a patent application. ${ }^{115}$ However, essentially all other countries of the world operate on a first-to-file system. ${ }^{116}$ This conflict allows for the situation to arise in which a patent for the same invention could be awarded to different parties in the United States versus other countries of the world. ${ }^{117}$ Also, in the United States a patent application is examined for novelty and obviousness in a formal ex parte proceeding by the United States Patent and Trademark Office (U.S.P.T.O.). ${ }^{18}$ "In many other countries, the patent application simply publishes after a period of time and is never examined except as to nonsubstantive formalities."119

107. See Sabatelli \& Rasser, supra note 87 , at 586.

108. See id.

109. See id.

110. See id.; see also 35 U.S.C. § 101 (2002).

111. See Sabatelli \& Rasser, supra note 87 , at 586-87.

112. Id. at 587. "For example, pharmaceutical products are excluded from patent protection in Argentina, Japan, Turkey, and Venezuela." Id.

113. Id.

114. See 35 U.S.C. $\$ 102(\mathrm{~g})(2002)$.

115. See Sabatelli \& Rasser, supra note 87, at 587.

116. See id.

117. See id.

118. See id.

119. Id. "Countries such as Egypt, Italy, Spain, and Switzerland follow this latter procedure." Id. There are other important areas of international non-uniformity. See Sabatelli \& Rasser, supra note 87, at 587. Examples of these non-uniformities, from the perspective of the United States, are as follows:

First, in the United States there is a requirement for disclosing the 'best mode' for making the invention that is known at the time of the filing of the patent. However, in most other countries there is no such best mode requirement, with the patent being required merely to disclose a single, but not necessarily the best, mode of carrying out the invention. Second, most countries provide for automatic publication of their patent applications eighteen months after filing. In the United States, all patent applications are currently kept secret, being prosecuted before the U.S.P.T.O. in an ex parte proceeding, and do not publish unless they are examined and allowed to issue. Third, in the United States, only 


\section{Global Patent Law HaRmonization BENEFITS .}

\section{A. The United States}

"The most divisive issue in the harmonization debate is whether the United States should adopt a first-to-file system."120 For the United States to be included in any meaningful patent harmonization treaty, it likely must abandon its first-to-invent system and adopt the first-to-file system. ${ }^{121}$ There are three reasons the United States should adopt the first-to-file system: (1) the first-to-file system is superior to a first-to-invent system; (2) the change will not pose a significant harm to American inventors; and (3) adoption of the first-to-file system will enable the United States to exact concessions from other nations to the benefit of this country. ${ }^{122}$

Adoption of the first-to-file system would benefit to the United States because of its superiority over the first-to-invent system. ${ }^{123}$ The first-to-invent system requires records to be kept that the first-to-file system does not. ${ }^{124}$ "The first-to-invent system results in complicated and expensive interference proceedings ${ }^{125}$ that would be unnecessary under a first-to-file system. ${ }^{126}$ The small, independent inventor is most always at a major disadvantage in an interference proceeding against a large corporation. ${ }^{127}$ Adoption of the first-tofile system satisfies the question of the right to a patent between interfering

the inventor can apply for a patent, although the patent later can be assigned. In most of the world, the assignee can also apply for the patent. Fourth, the United States provides for a twelve-month grace period after public disclosure of an invention during which the inventor can modify and optimize the patent application. The remainder of the world récognizes no such grace period. Fifth, the United States distinguishes between domestic and foreign prior art as a statutory bar to patentability. There is little uniformity in the rest of the world for dealing with this domestic/foreign prior art dichotomy. Sixth, interpretations and enforcement procedures vary widely from country to country.

Id. at 587-88.

120. Robert W. Pritchard, The Future Is Now - The Case for Patent Harmonization, 20 N.C. J. INT'LL. \& COM. REG. 291, 312 (1995).

121. See id.

122. See id.

123. See id. at 313.

124. See id. "American inventors are required to keep accurate records of all acts of invention in the event that a patent is involved in an interference proceeding and the inventor is required to prove conception, reduction to practice, and diligence." Id.

125. "In patent terms, when two independent inventors lay claim to the patent for the same invention, a 'priority dispute' arises." Sean T. Carnathan, Patent Priority Disputes--A Proposed Re-Definition of "First-to-Invent,", 49 ALA. L. REV. 755, 756 (1998). The mechanism for resolving the dispute before the United States Patent \& Trademark Office [U.S.P.T.O.] is called an interference. II.

126. Pritchard, supra note 120 , at 313.

127. See id. "Currently, interference proceedings are 'cumbersome, inadequate, and often seemingly inexplicable."” ld. 
parties by a quick examination of filing dates, thus eliminating the need for interference proceedings. ${ }^{128}$ This would greatly diminish the cost of the patenting process to the parties and the patent society. ${ }^{129}$ Also, a first-to-file system may prove to be a significant advantage to small companies and independent inventors when contrasted with the complications, costs, and difficulties associated with proving that an inventor made an invention first under the current system. ${ }^{130}$ "Adoption of a first-to-file system will end the inherent disadvantage of independent inventors in interference proceedings against large corporations, as a simple comparison of filing dates will end any question of priority."131 The United States should be receptive to this since it is thought to view patent law more for the protection of the inventor than for the public benefit. ${ }^{132}$

The first-to-file system also brings predictability, whereas the first-toinvent system does not. ${ }^{133}$ The first-to-file system does not require anything more than the date of filing to prove who was the first to deserve the patent, unlike the first-to-invent system. ${ }^{134}$ Adoption of the first-to-file system will settle the question of inventorship at the time the applicant files an application, and will end the uncertainty and unpredictability that can arise under the current first-to-invent system. ${ }^{135}$ Also, it is unlikely that changing to the firstto-file system would be detrimental to many parties involved. ${ }^{136}$

128. Id.

129. See id.

130. See id.

131. Pritchard, supra note 120 , at 313 .

132. See generally Victoria Cooper, U.S. Adoption of the International Standard of Patent Priority: Harmony or Schizophrenia, 16 LOY. L.A. INT'L \& COMP. L.J. 697 (1994).

133. See Pritchard, supra note 120 , at 313.

134. See id. Under 35 U.S.C. $\$ 102$ (g) of the Patent Act, a person is not entitled to a patent if another person invented the invention first. 35 U.S.C: $\$ 102$ (g) (2002). See, e.g., New Idea Farm Equip. Corp. v. Sperry Corp., 916 F.2d 1561, 1566-67 (Fed. Cir. 1990). The Court of Appeals for the Federal Circuit held that "[i]t is well established that, in a priority contest, the party first to conceive and first to reduce to practice prevails." Id. Therefore, at any time during the patent term a third party has the opportunity to demonstrate a prior act of invention that can destroy a patent under $\S 102(\mathrm{~g})$. See Pritchard, supra note 120 , at 314. The President of the American Intellectual Property Lawyer's Association has stated that one advantage to a first-to-file system is "an end to the cumbersome interference procedure for defining inventorship, and more certainty and simplicity in the application process." See id. at 314.

135. See Pritchard, supra note 120 , at 314.

136. See id. "Adoption of a first-to-file system does not affect the vast majority of patent applicants, and the change would not be nearly as harmful as some predict." Id. "First, most American companies already operate on a first-to-file system, so a change to first-to-file would not have a substantial effect." Id. "Since the rest of the world awards the patent to the first person to file a patent application, American companies with foreign interests who are already bound by the first-to-file system in other countries would not be adversely impacted by a change to first-to-file in the United States." Id. "Large American corporations would not be affected by a change to a first-to-file system, and neither would most independent inventors." Id. "Statistics for the fiscal years from 1988 to 1991 indicate that out of approximately 170,000 patent applications, the average number of inventors who were second to file, but first to invent, was only fifty-five per year." Pritchard, supra note 1200 , at 314 . "Because only a fraction of 
By converting to the first-to-file system, the United States would have more leverage to demand concessions from the rest of the world on other patent harmonization issues. ${ }^{137}$ One successful demand would be the establishment of an international grace period. ${ }^{138}$ Currently, United States patent law grants a one-year grace period during which a public disclosure will not be considered prior art for the purpose of a federal statutory bar ${ }^{139}$ to patentability. ${ }^{140}$ This is in conflict with most of the rest of the world. ${ }^{141}$ The United States could potentially get other countries to adopt an international grace period, thus allowing American inventors public disclosure without forfeiting international opportunities. ${ }^{142}$

patentees in the United States are independent inventors, the statistics demonstrate that only one to four independent inventors per year would lose a patent under the first-to-file system out of over 170,000 applications that are filed every year." Id. "Furthermore, if the United States adopted a first-to-file system, the first inventors in that small fraction of cases would have the incentive to file sooner, thus reducing the number of applicants who are first to invent but second to file to almost zero." Id. at 314-15. "Thus, a change to first-to-file would not affect a significant number of inventors." Id. at 315 . "The United States should not refuse to adopt meaningful patent harmonization because of the possibility of a tiny fraction of first inventors losing patent rights due to delay in filing." Id.

137. See id. at 318. "If the United States were to give up the first-to-invent system in favor of first-to-file, it could demand reform in other countries to the benefit of American inventors, both corporate and independent." Pritchard, supra note 120, at 317 . It has been stated that harmonization presents the United States with a unique opportunity to strengthen the protection for the invention of American industry and individual inventors around the world. See id.

138. See id.

139. See generally 35 U.S.C. $\$ 102$ (2002).

140. See Pritchard, supra note 120, at 319. "The grace period enables American inventors to publish results of tests and to make preliminary public sales without fear of losing the right to possibly valuable patent protection." $I d$.

141. See id. "Most other countries operate on the theory of absolute novelty without a grace period, however, and will not issue a patent if there has been any disclosure prior to the date of filing." Id. "As a result, when an American inventor publishes an invention in reliance upon the grace period, he or she automatically forfeits any right to a patent "in virtually every country other than the United States." Id. "While most large American corporations have adapted to the absolute novelty requirements of other countries, independent inventors are often not aware of the adverse consequences of early publication, and therefore forfeit foreign rights unknowingly." Id. "University researchers that place a premium on publication often give up foreign patent rights in favor of early publication." Pritchard, supra note 120, at 319. "The result is that foreign companies have a repository of information in the U.S. Patent Office in the form of patents that can only be valid in this country due to the grace period." Id. at 319. "This information can be freely used in the rest of the world, and the American inventor has no protection." Id. This problem could be rectified if the United States was able to pressure the rest of the world to adopt an international grace period." Id. "American adoption of a first-tofile system as part of a complete harmonization package would enable the United States to pressure the rest of the world to adopt an extremely valuable grace period that would benefit small inventors and universities in this country." Id. "This benefit alone would justify the change to first-to-file; a small price to pay for international protection of American innovation." $\mathbf{l d}$.

142. See Pritchard, supra note 120, at 319. 
Leverage would also help deal with the doctrine of equivalents. ${ }^{143}$ In the United States, "if a device that is not precisely identical to the patented device 'performs substantially the same function in substantially the same way to obtain the same result, ${ }^{144}$ a patentee may invoke the doctrine of equivalents to claim infringement."145 This doctrine prevents potential infringers from subtly altering or making insignificant substitutions to a patented device to avoid infringement, while still gaining all of the benefits of the innovation. ${ }^{146}$ However, the nature of the laws and the judicial practice of some countries have resulted in courts' narrow interpretations of patents, thus allowing an infringer who made minor alterations to a patented innovation to escape liability. ${ }^{147}$ Adopting a first-to-file system would allow the United States to pressure other countries to adopt the doctrine of equivalents, thereby increasing worldwide protection for American inventors. ${ }^{148}$

An additional benefit to harmonization would be to allow American inventors to file patent applications in English and supply a translated application at a later time. ${ }^{149}$ Currently, American inventors must obtain a translation of the application before filing, resulting in two problems when attempting to obtain protection abroad. ${ }^{150}$ The first problem is caused when an American inventor is in a race to submit a patent application in a foreign country against another inventor who has the application already in that language. ${ }^{151}$ The American inventor is placed at a disadvantage due to the delay in obtaining a translation. ${ }^{152}$ The second problem occurs if any error made during translation which is essential to the scope of the claims or the patentability of the entire invention, the error is not correctable, and the American inventor either loses the patent or obtains greatly reduced coverage due to a clerical mistake. ${ }^{153}$ Allowing the English language original application to serve as the priority date of the patent for purposes would solve the first problem. ${ }^{154}$ The second problem is solved if the English language application would be considered the official application for purposes of correcting

143. Id.

144. See id.; see also Sanitary Refrigerator Co. v. Winters, 280 U.S. 30, 42 (1929). The Court observed: "A close copy which seeks to use the substance of the invention, and although showing some change in form and position, uses substantially the same devices, performing precisely the same offices with no change in principle, constitutes an infringement." Id. (citing Ives v. Hamilton, 92 U.S. 426, 430 (1875)).

145. Pritchard, supra note 120 , at 319.

146. Id.

147. See id.

148. See id. at 320.

149. See id.

150. See id.

151. See Pritchard, supra note 120 , at 320.

152. See id.

153. See id.

154. See id. 
typographical or clerical errors in translation. ${ }^{155}$ If the United States adopted a first-to-file system as part of a harmonization package, it could demand this change from all other nations, thereby benefiting American inventors. ${ }^{156}$

"The costs of a universal, harmonized patent system would be greatly reduced, thereby increasing the small inventor's accessibility to the world market." 157 A universal first-to-file system would eliminate the transaction costs required for securing multiple licenses for world-wide purposes. ${ }^{158} \mathrm{~A}$ harmonized system of international patent laws would also reduce the time and expense required to obtain international protection. ${ }^{159}$ Specifically, harmonization of patent laws would save independent inventors and university researchers' time and money, and would expand their zone of protection to nations that they were never able to reach under the isolationist first-to-invent system. ${ }^{160}$

The benefits of patent harmonization throughout the world would cost the United States the relatively small price of moving from a first-to-invent system to first-to-file. ${ }^{161}$ Implementing the first-to-file system in this country will allow the United States to join in the efforts of the international community to harmonize international patent law. ${ }^{162}$ "Harmonization will enable the American inventor to expand the zone and scope of patent protection around the world, and adoption of a first-to-file system is a small price to pay for international acceptance and recognition of American innovation."163

\section{B. The European Community}

Even though Europe ${ }^{164}$ has endeavored to make strides towards continental harmonization, i.e., the Euro, European patent law has failed to become harmonized. ${ }^{165}$ Currently, Europe has two systems under which

155. See id. "An agreement between the United States and Japan signed on January 20, 1994, provides that American inventors will be permitted to file an English language application to establish a priority date so long as a Japanese translation follows "in a reasonable period of time." Id. at 320-21.

156. See Pritchard, supra note 120 , at 321.

157. Id.

158. See id.

159. See id.

160. See id.

161. See id.

162. See Pritchard, supra note 120 , at 321.

163. Id.

164. For purposes of this Note, the European countries Part IV(B) refers to throughout consist of the nations that subscribe to the European Patent Office's way of issuing patents. See infra Part IV(B). These countries are listed on the European Patent Office website at http://www.european-patent-office.org/epo/members.htm (last visited Nov. 25, 2002).

165. See Kara M. Bonitatibus, The Community Patent System Proposal and Patent Infringment Proceedings: An Eye Towards Greater Harmonization in European Intellectual Property Law, 22 PACE L. REv. 201, 202 (2001). For more on the European community's attempt to harmonize its patent laws, see Christopher Heath, Harmonizing Scope and Allocation of Patent Rights In Europe - Towards A New European Patent Law, 6 MARQ. INTELL. PROP. L. REV. 11 (2002). 
inventors can choose to protect inventions by patent - a national and a European Patent system. ${ }^{166}$ The national system is country specific. ${ }^{167}$ Each country can issue its own national patent and all proceedings related to that patent are governed by the granting country's laws. ${ }^{168}$ The European Patent Office $^{169}$ (EPO) grants the European patents. ${ }^{170}$ These patents are essentially a bundle of national patents. ${ }^{171}$ This European patent system allows a single application and granting procedure. ${ }^{172}$ However, each nation which is a party to the European Patent Convention ${ }^{173}$ (EPC) is allowed to maintain certain requirements regarding its own patent system, such as keeping translations of the patent in its own language. ${ }^{174}$ Besides the one application, each patent exists separately in each sovereign state from which it is issued. ${ }^{175}$

These two systems cause inconsistencies and unpredictability in patent protection. ${ }^{176}$ "Such uncertainty and unpredictability result from the fact the

166. See Bonitatibus, supra note 165 , at 202.

167. See id. at 203.

168. See id.

169. The EPO describes itself on its website:

The European Patent Office (EPO) grants European patents for the contracting states to the European Patent Convention (EPC), which was signed in Munich on [October 5, 1973] and entered into force on [October 7, 1977]. It is the executive arm of the European Patent Organization, [sic] an intergovernmental body set up under the EPC, whose members are the EPC contracting states. The activities of the EPO are supervised by the Organization's [sic] Administrative Council, composed of delegates from the contracting states.

EPO, Information About the EPO - The European Patent Office, available at http://www.european-patent-office.org/epo/pubs/brochure/general/e/epo_general.htm (last visited Nov. 25, 2002). The EPO also provides its history on the website:

The EPO was set up by the contracting states to the EPC [European Patent Convention] with the aim of strengthening cooperation between the countries of Europe in the protection of inventions. This was achieved by adopting the EPC, which makes it possible to obtain such protection in several or all of the contracting states by a single patent grant procedure, and establishes standard rules governing the treatment of patents granted by this procedure. More than two decades have clearly demonstrated the advantages of this approach. Looking to the future, the EPO is continuing its efforts to optimize [sic] the European patent system by making it more efficient and cost-effective, and better adapted to the applicant's needs.

$\mathrm{EPO}$, Information About the EPO - Origins and perspectives, available at http://www.european-patentoffice.org/epo/pubs/brochure/general/e/origins_e.htm\#fn (last visited Nov. 25, 2002) [hereinafter EPO].

170. See Bonitatibus, supra note 165 , at 203.

171. See id.

172. See id.

173. See generally EPO, supra note 169.

174. See Bonitatibus, supra note 165 , at 203. This is a main requirement EPC members are allowed to keep. See id.

175. See id.

176. See id. Uncertainty and unpredictability obviously denigrate the very purposes of the patent system, which is to allow the creator of certain kinds of inventions that contain new ideas to keep others from making commercial use of those ideas without the creator's permission. See id. 
national courts of Europe 'continue to apply differing procedural rules and employ different approaches in patent infringement actions." 177 A large weakness of the current EPC patent system is the cost of translating an application to obtain a patent. ${ }^{178}$ The cost of a European patent, which includes translation costs, as well as other various fees, is three to five times more than a Japanese or United States patent. ${ }^{179}$ "An acceptable level of cost for a European patent should be comparable to the cost of a patent covering the same economic area ...."180

Because of the greater costs of the European patent, companies often cannot afford extending coverage of its patents to all members of the European Union. ${ }^{181}$ Instead, companies compromise and designate only a few countries, which are key countries in terms of market and competition. ${ }^{182}$ This proves detrimental to the smaller countries. ${ }^{183}$ These problems urgently need a remedy to this high cost situation, which does not provide any incentive for inventors to apply for a patent in Europe. ${ }^{184}$

Another major disadvantage for the European system is a lack of a "Community Patent Appeal Court," analogous to the federal Court of Appeals system in the United States. ${ }^{185}$ Under the EPC, disputes, including infringement proceedings, are resolved in the national courts that are competent. ${ }^{186}$

177. Id.

178. Bonitatibus, supra note 165 , at 209-210. A study conducted for a proposal to unify the European community's patent system estimates the cost of an average European patent as approximately 30,000 Euros. See id. at 210 . The breakdown of the total cost is as such: fourteen percent for fees due the European Patent Office; eighteen percent for representation before the EPO; thirty-nine percent for translations required by the contracting states; and twenty-nine percent for renewal fees paid to member states. See id. A patent must be translated into the relevant official languages of a designated country in order for the patent to be valid. See id. at 211. "Potentially, the patentee may be required to translate their patent into all of the eleven official languages." Id. "Arguments raised for the necessity of this requirement include that "translations are necessary to ensure full access to patented technology by industry and research institutions in all E.C. countries." Id. "These costs of translation, though burdensome to all patent applicants, will be exceptionally burdensome to small inventors with limited marketing areas." Bonitatibus, supra note 165, at 211.

179. See id.

180. Id. at 210 .

181. See id.

182. See id. at 211.

183. See id.

184. See Bonitatibus, supra note 165 , at 211.

185. See id.

186. See id. at 212 . "[I]n principle, "there can be 15 different legal proceedings, with different procedural rules in every Member State and with the risk of different outcomes." Id. "So, while the deficiency of a common court permits a considerable advantage to a plaintiff patentee who engages in forum shopping in the European Union, it also leads to increased costs of litigation and the potential for inconsistent results and, undesirably, unpredictable protection of one's patent." Id. 
There are other minor weaknesses of the European system because of its lack of harmonization. ${ }^{187}$

A harmonized patent system would allow a patent to be registered for all of the European Union members - allowing the patent to issue in all nations instead of an inventor having to choose at the outset ${ }^{188}$ Also, the patent would be subjected to only one interpretation throughout the world. ${ }^{189}$ There would be one unified court or, at the least, one unified process for proceedings ${ }^{190}$ allowing one judgment to be passed on a patent. ${ }^{191}$ Finally, costs to obtain a patent throughout the world for the European community could be reduced because of translation guidelines that may be set. ${ }^{192}$

\section{Developing Countries}

Developing countries not only provide insufficient patent protection under the substantive law, but often inadequately enforce the legal standards that do exist. ${ }^{193}$ This leads to inadequate protection of patents. ${ }^{194}$ Several developing countries have deficiencies in their patent systems. ${ }^{195}$ For instance, businessmen of developing countries resorted to various techniques to minimize their losses of intellectual property, which have limited their ability

187. Id. "Additional weaknesses of the current system include the speed (or lack thereof) in patent infringement proceedings, and the "high cost of renewal fees and issues associated with secret prior user rights." Bonitatibus, supra note 165, at 212 . "As stated and demonstrated above, renewal fees paid to member states are estimated to be approximately $29 \%$ of the cost of an average European patent." Id. "The time involved in patent infringement proceedings may be significant; however, it is noted that "it is more important to reach the right decision after proper consideration than to reach the wrong decision by rushed justice." Id. "Thus, some debilities of the current system may actually be necessary flaws." Id.

188. See id. at 230.

189. See id. "Thus, 'there would be no need to be concerned about interpretation, or for that matter, the applicability of cross-border injunctions." Bonitatibus, supra note 165, at 230.

190. See infra Part VI.

191. See Bonitatibus, supra note 165, at 231.

192. Id.; see infra Part VI.

193. See Marshall A. Laeffer, Protecting United States Intellectual Property Abroad: Toward a New Multilateralism, 76 IOWA L. REV. 273, 275 (1991).

194. See id. at 277.

195. Robert M. Sherwood, Why a Uniform Intellectual Property System Makes Sense for the World, in Global Dimensions of INTEllectual PROPERTY Rights IN SCIENCE AND TECHNOLOGY 68, 73 (Mitchel B. Wallerstein, et al. eds., 1993). "This work has been concentrated in Brazil, where more than 20 weeks were spent, but interviews were also conducted in Mexico, Argentina, Colombia, Venezuela, and in what are now Russia, Belarus, and Estonia." Id. "The effort has been to talk to with people who have a direct stake in the local intellectual property system." Id. "More than 200 interviews were conducted, mainly with local businessmen, but also with university researchers, venture capital firm owners, ranchers, research park directors, state enterprise officials, and then, to help in formulating reflections, with local academic economists." Id. 
to make technological advances. ${ }^{196}$ In universities, researchers who have come up with inventions, sometimes by surprise, found they had to start their own company to commercialize their inventions. ${ }^{197}$ Unfortunately, most researchers are not aware of existing protections to maximize the financial and technological potential of their inventions. ${ }^{198}$

Also, venture capital firms cannot obtain useful information about the underlying technology on which start-up firms base their requests for venture capital because the typical start-up company fears losing its technology to the venture capital firm. ${ }^{199}$ Consequentially, the venture capital firms do not even reach the stage of contemplating whether they are willing to invest in such start-up firms. ${ }^{200}$

Also, research park directors reported they are having difficulty raising funds to support their work. ${ }^{201}$ The expected synergy in these research parks has not appeared at the levels observed in countries with high-stimulation systems. ${ }^{202}$ "Both deficiencies are traceable to low protection environments." 203

Weak intellectual property protection results in very high costs on the development process. ${ }^{204}$ The costs are mostly located in the area of opportunity losses. ${ }^{205}$ "Counting things that do not happen is frustrating, but this does

196. See id. at 74. One frequent way competitors get their hands on technology is to hire away key employees, a kind of "predatory hiring." See id. "To defend against this, businessmen segment their technology, exposing the fewest possible workers to each segment." See Sherwood, supra note 195 , at 74 . In conjunction with other techniques, this works to a limited degree to prevent technology loss, but those same techniques have a negative effect on employee training. See id. "Human resource development suffers in silent, unnoticed ways in low-protection intellectual property environments." Id. "Most important, as noted, there seems to be a direct connection between low protection and lack of stimulation to perform in-house research." Id.

197. See id. Most researchers that stumble onto an invention are usually ill equipped to function as entrepreneurs, they neglect their students, and worse, they neglect their ongoing research. See id. "Some, who have studied abroad, understood that if they could effectively protect their inventions with patents[,] ... it would be possible to license the invention to others better prepared to commercialize the new technology." Sherwood, supra note 195, at 74.

198. See id.

199. See id.

200. See id.

201. See id. "This is a serious problem, particularly when government research expenditure diminishes." Id.

202. See Sherwood, supra note 195 , at 74.

203. Id. "Normally, private funds will not be invested in research, other than as an act charity, if the expected results cannot be appropriated through the application of the tools of intellectual property." Id. "Within research parks, investigators who are brought together to stimulate each other's thinking, are instead wary of sharing proprietary technical knowledge for fear it will be misappropriated by others at the center." Id. "In countries with adequate protection, this fear is overcome by enforceable confidentiality agreements and other protective mechanisms." Id.

204. See id.

205. See Sherwood, supra note 195 , at 75. 
not mean the costs are not great."206 To measure these costs research methods are needed. ${ }^{207}$

Examples exist that demonstrate that some of these problems can be alleviated by implementing a harmonized system. ${ }^{208}$ One example is found in the activity patterns following a developing country's intellectual property upgrades. ${ }^{209}$ For instance, after Mexico reformed its patent laws in June 1991, large numbers of patent applications were filed by Mexican nationals. ${ }^{210}$ Apparently, the level of protection rose such that it made a difference to local activity. ${ }^{211}$

A common assumption is that all technology comes from developed countries. $^{2 / 2}$ This leads to the belief that developing countries cannot be expected to generate technology. ${ }^{213}$ "As a consequence of this thinking it is presumed that weak protection for intellectual property will assist in obtaining developed country technology at little or no cost." 114 The possibility that developing countries could generate valuable technology comes almost as a shock. ${ }^{215}$ However, this is precisely the point of urging strong intellectual property protection in developing countries, so that this possibility can be realized. ${ }^{216}$ "It is far less likely to be realized without protection." 217

\section{IMPLementation of a Globally HaRmonized Patent System}

Having identified the benefits of a globally harmonized patent system, discussion of how these benefits can be implemented is now necessary. This section will provide two different types of global patent law systems as possible ways of implementing harmonization benefits. The first comprises

206. Id.

207. See id.

208. See id. at 72 .

209. Id. at 72.

210. See id.

211. See Sherwood, supra note 195, at 72. "Although the changes to Mexico were probably the most sweeping, reforms in Korea, Taiwan, Singapore, Brazil (copyright for software), and China present interesting before-and-after situations." Id. Even though this note deals exclusively with patent law, other intellectual property types may still give some insight. See id. "A small but striking example of before-and-after shift comes from Columbia where copyright protection for software took effect in 1989. More than 100 Columbian nationals have since produced application software packages that have been registered with the copyright office, with hundreds more written but not registered." $I d$. "Many of these customized programs help run local industrial manufacturing processes." Id. "This example hints that there is a great deal of very useful technology that could be generated in developing countries by local people, given the stimulus of an intellectual property system that works." Id.

212. See Sherwood, supra note 195 , at 72.

213. See id.

214. Id.

215. See id.

216. See id.

217. Id. 
an extreme system where the world would operate under one uniform system. The second system would have some jurisdictional variation, but would still have underlying uniform principles to which nations would adhere.

\section{A. The World Patent System}

\section{Office Set-Up}

The overriding characteristic of a World Patent System (WPS) is that it would be a multinational organization established, managed and administered, not by national patent offices, but by international civil servants in a multinational setting established by treaty. ${ }^{218}$ In its primordial stages it would operate in parallel with national systems. ${ }^{219}$ However, to be truly effective, it will not grant a bundle of national patents - as is now done by the European Patent Office ${ }^{220}$ - but a single unitary patent respected in all of the member states. ${ }^{221}$

The WPS would have regional offices to search and examine patent applications, to grant patents, and to staff regional branches or "circuits" of a World Patent Court. ${ }^{222}$ Eight candidates would likely be worthy of a regional office: Europe, Japan, China, Latin America, Africa, Eurasia, East Asia and North America. ${ }^{223}$ However, the WPS must not be viewed as "belonging" to a specific region or constituency. ${ }^{224}$

\section{Language Requirements}

Under the WPS, the first-to-file system would be implemented as well as the grace period, both discussed earlier. ${ }^{225}$ However, a language agreement would also need to be reached. ${ }^{226}$ "Currently, as many as two dozen languages must be used to reasonably cover a single invention internationally."227 The $\mathrm{EPO}^{228}$ now has three "official" languages - English, German and French - in which examinations are conducted. ${ }^{229}$ However, the bundle of patents elected at the time of the EPO grant must be translated into the respective language of

218. See Mossinghoff \& Kuo, supra note 19, at 547.

219. See id.

220. See infra Part V(B).

221. See Mossinghoff \& Kuo, supra note 19, at 547.

222. See id.

223. See id. at 547-48. "Deciding where to locate offices of multinational organizations has traditionally been a matter of intense diplomatic negotiations involving [several] factors." Id. at 548. "A strong case can be made for each of these eight locations-and perhaps several more." Id.

224. See id.

225. See supra Part IV.

226. See Mossinghoff \& Kuo, supra note 19, at 551.

227. $I d$.

228. See supra Part V(B).

229. See Mossinghoff \& Kuo, supra note 19 , at 551. 
each selected country. ${ }^{230}$ No less than ten translations would be required at the end of the examination process by electing all of the EPO countries. ${ }^{231}$ With additional EPO memberships from Central/Eastern Europe, ${ }^{232}$ the costs of translations in the EPO alone could simply become overwhelming. "This European Tower of Babel will have many neighbors if the newly industrialized countries of East Asia and other regions insist on using their own languages in their emerging patent systems."234 A WPS that would use all of the languages of the world would clearly not be reasonable. ${ }^{235}$

English should be considered the world language of trade, science, technology, and intellectual property. ${ }^{236}$ "By conservative estimates, 750 million persons speak English, almost half of them as their native language."2377 Two-thirds of the world's scientific information is published in English, ${ }^{238}$ and eight-five percent of all information now stored in computers is in English. ${ }^{239}$ A large majority of EPO-filed cases are now in English, with those filed in French accounting for less than ten percent. ${ }^{240}$ "Cases in the EPO originating from outside Europe - notably from the United States and Japan - are virtually all in English."241 The EPO, Japan patent office and Chinese patent office all require their patent examiners to be fluent in English. ${ }^{242}$ Choosing English as the language of the WPS ${ }^{243}$ simply recognizes that English is the only practical choice for a World Patent System that will demand a common world language. ${ }^{244}$

Given the success of the Japanese Patent Office (JPO) in moving to a "paperless" environment, and the corresponding strides in the United States and the EPO, the World Patent System would use a single electronic database

230. See id.

231. See id. id.

232. Such as Poland, Bulgaria, Romania, Hungary and Czech and Slovak Republics. See

233. See id.

234. Id.

235. See Mossinghoff \& Kuo, supra note 19, at 551.

236. See id.

237. Id. at 551-52. "If India and China are added, some estimates range toward two billion." Id. at 552 .

238. See Alex Y. Seita, Globalization and the Convergence of Values, 30 CORNELL INT'L L. J. 429,455 n. 80 (1997).

239. See Mossinghoff \& Kuo, supra note 19, at 552.

240. $I d$.

241. Id.

242. See id. "A proposed East Asia Patent Office B a planed regional patent system of Indonesia, Republic of Korea, Malaysia, Singapore, Taiwan, Thailand, among others-is now being designed with the assumption that English will be the single language employed." Id.

243. See id. Choosing English as the WPS language should in no way be an affront to the rich culture and history of France, Spain, Portugal or any other country or region. See Mossinghoff \& Kuo, supra note 19, at 552.

244. See id. "Just as English has been used as the only language for air traffic control worldwide for decades, there should be an agreement that English will be the language of the WPS." Id. 
of worldwide prior art against which to search and examine patent applications. ${ }^{245}$ Eventually, machines may be fully capable of "conversing" with patent professionals. ${ }^{246}$ Even though patents would be examined and enforced in English, the WPS should take advantage of machine translations to provide patent disclosures to all countries in their own languages. ${ }^{247}$ "This will reinforce the use of patents as a uniquely rich source of scientific, technical and business information." 248

\section{The WPS Judicial System}

As noted ${ }^{249}$ patents essentially are national instruments to be enforced by national courts. ${ }^{250}$ The WPS envisioned here would be in sharp contrast to this. ${ }^{251}$ "There would be a single World Patent Court (WPC) with branches or 'circuit' courts at the locations of the regional patent offices to decide appeals from those regional offices of the World Patent System and to hear and decide enforcement actions, including both infringement and validity issues."252 "Under the treaty establishing the [WPS], decisions of the [WPC] would be given full faith and credit and implemented and enforced through national courts of all of the member states."253

Instead of appeals and enforcement actions being heard by national jurists, panels of expert multinational jurists, appointed through a merit system administered by the World Patent System would be used. ${ }^{254}$ Patent enforcement trials would be presided over by what the United States would refer to as hearing examiners or special magistrates, throughout the nations that establish the WPS. ${ }^{255}$ "To ensure impartiality, the multinational jurists who make up the [WPC] and the hearings examiners or special magistrates would be assigned, not based upon their nationality, but rather on their technical expertise and to assure a fair and competent balance in any hearing or enforcement action." 256 For instance, an appeal in a United States regional court could be heard and decided by a three-judge panel - one from Europe, one from Latin America, and one from Asia - depending on the results of impartial, probably random, assignments. ${ }^{257}$ "The [WPC] would have to have

245. See id.

246. See id.

247. See id.

248. See Mossinghoff \& Kuo, supra note 19, at 552.

249. See supra Part II. "There have been limited instances of cross-border enforcement of patents ...." Mossinghoff \& Kuo, supra note 19, at 553.

250. See Mossinghoff \& Kuo, supra note 19, at 553.

251. See id.

252. Id.

253. Id.

254. See id.

255. See id.

256. Mossinghoff \& Kun, supra note 19, at 553.

257. See id. 
firm control over pretrial and trial procedures in preparing cases for decisions, drawing upon the best experience of the member states."258 Alternate dispute resolution based upon the best international models would be strongly encouraged to lower the cost of patent enforcement actions. ${ }^{259}$

Some international treaties shed some light about the potential of the WPS. ${ }^{260}$ The TRIPS Agreement ${ }^{261}$ achieves more harmonization aspects faster than anyone could have predicted just one decade ago. ${ }^{262}$ "It demonstrated quite dramatically that political will, implemented by skilled and innovative negotiators, can overcome generations of local biases."263

Although the WPS looks good theoretically, a high level of statesmanship is required in reaching agreement among the major countries of the world on such a system. ${ }^{264}$ Also, there are a host of critically important but lesser matters that would need to be agreed upon in establishing a World Patent System. ${ }^{265}$ "It is certain that all of the existing national/regional patent systems of the world would remain in place during the initial years of a World Patent System to function in parallel with it until all concerned gained experience and comfort with the effectiveness of the new system."266

\section{B. Baseline Requirement System for World Patent System}

Unlike the detailed system outlined above, another alternative to a globalized patent law system may be based on a basic set of rules while each nation maintains similar performance levels. ${ }^{267}$ This system would only need to maintain certain characteristics instead of matters being decided by one central court with world-regional branches. ${ }^{268}$

The first characteristic of a harmonized system is that each nation need not be identical. ${ }^{269}$ Some feel that identical systems would require uniformity beyond that needed to achieve the beneficial effects of a uniform system. ${ }^{270}$

258. Id.

259. See id.

260. See id. at 553.

261. See supra Part III(D).

262. See Mossinghoff \& Kuo, supra note 19 , at 553.

263. Id. at 553-54.

264. See id. "[C]ertainly no less than that required when [the U.S.] Founding Fathers delegated to the new Federal Government the exclusive power to grant patents, which until then had been granted by individual states." Id.

265. See id.

266. Id.

267. See generally Sherwood, supra note 195.

268. See supra Part VI(A)(3).

269. See Sherwood, supra note 195, at 68 (emphasis added).

270. See id. "Harmonization of laws, procedures, and rules in every country is not called for, although that could follow and is indeed already an objective being sought by some countries." Id. at 69 . 
This system would not contain just one of one court of appeals or one single patent office. ${ }^{27 !}$

The second characteristic is congruence. ${ }^{272}$ Congruence would be based on robust similarities of outcome from one country to another, instead of identical statutory provisions. ${ }^{273}$ The congruence would allow the large issues to be easily considered without having to research nations individually. ${ }^{274}$ Any differences existing between nations would be handled by specialty attorneys. ${ }^{275}$

The third characteristic is stimulation. ${ }^{276}$ "People involved in the process of invention, technical advancement, and creative expression will be stimulated by confidence that the results of their efforts can be safeguarded from misappropriation and unauthorized copying, no matter which country becomes the location of their activity."277

A quasi-numerical based model best exemplifies how these characteristics would create an efficient globally harmonized patent system. ${ }^{278}$ This system rates countries from a scale from one to one-hundred on intellectual property systems relative to one another. ${ }^{279}$ For this rating, the entire intellectual property system is taken into consideration. ${ }^{280}$ "As examples, Germany can be rated at slightly more than 90 , the United States and some of the European countries in the high 80s, and Mexico after its . . reforms at about 75, whereas Argentina and Brazil currently rank in the 30s and 40s."28.

Only countries with a system above seventy will produce positive results. ${ }^{282}$ The results can be measured in terms of three critical occurrences: private venture capital firms become willing to invest in technology-based start-up companies, valuable technical knowledge flows more readily from

271. See id.

272. See id.

273. See id.

274. See Sherwood, supra note 195 , at 68 . For a discussion on first-to-invent versus firstto-file see supra Part V.

275. See Sherwood, supra note 195, at 68. "Where congruence does not exist, people other than lawyers are troubled by system differences when making investment, research, and licensing decisions." Id.

276. See id.

277. Id. "The knowledge that others can be prevented from unauthorized copying has been widely experienced as a powerful stimulus to invest time, resources, and effort in inventive activity." Id. at 69. "What constitutes reasonable protection can, in part, be gauged by the degree to which this stimulation is active in the technology-producing infrastructure of a country." Id.

278. See Sherwood, supra note 195, at 69.

279. See id.

280. See id. This consists of substantive rules, administrative practice, and judicial enforcement. See id.

281. Id.

282. See id. 
university laboratories to the marketplace, and local firms' willingness to devote substantial resources to internal research. ${ }^{283}$

Some commentators feel that this kind of patent system would be better in the long run ${ }^{284}$ than a system such as the WPS. ${ }^{285}$ This idea is based on the fact that some variation from jurisdiction to jurisdiction would be valuable. ${ }^{286}$ The theoretical literature on this "jurisdictional variation" posits that the primary reason for such variation is to permit each jurisdiction to match its laws to the unique tastes and preferences of its population. ${ }^{287}$ This argument has a strong and weak version, with the weaker being more relevant to the international context. ${ }^{288}$ The weaker argument assumes a stable set of preferences within each jurisdiction and concludes that the diverse laws of each jurisdiction more closely match the individual preferences within the jurisdiction than would a uniform set of laws imposed across all jurisdictions. ${ }^{289}$ An example of this in the patent context exists relating to the TRIPS Agreement' ${ }^{290}$ flexibility. ${ }^{291}$ The TRIPS Agreement itself recognizes

283. See Sherwood, supra note 195, at 69.

284. See John. F. Duffy, Harmony and Diversity in Global Patent Law, 17 BERKELEY TECH. L.J. 685 (2002). There are those who feel even more strongly against patent harmonization. For a summary of the attacks on patent harmonization see Coe A. Bloomberg, In Defense of the First-to-Invent Rule, 21 AIPLA Q. J. 255 (1993); see also Charles R.B. Macedo, First-to-File: Is American Adoption of the International Standard in Patent Law Worth the Price?, 18 AIPLA Q. J. 193 (1990).

285. See infra Part VI(A).

286. See generally Duffy, supra note 284 . Historically, patent law owes its birth not to harmony but to diversity of law. See id. at 691 . A fifteenth century Venetian statute pioneered patent law, and was an experiment in law. See id. This statute was a departure from the classical hostility to government-sanctioned exclusive rights. See id.

287. See id. at 703.

288. See id. "The strong version assumes individuals are free to move between jurisdictions and concludes that, under certain assumptions, the resulting diversity of laws between jurisdictions reflects an optimal provision of public goods." Duffy, supra note 284, at 704. "While this version of the argument is important for diversity in local and state jurisdictions, it has little force in the international setting because changing nationality is relatively expensive for individuals." Id.

289. See id. This argument is relied upon in explaining why the GATT/WTO structure does not attempt to harmonize worldwide regulatory law:

Uniform health, labor, safety, and environmental regulations are unlikely to be appropriate for all members of the world trading community, as members of the WTO vary widely in their levels of development. As a result, they will rationally choose different regulatory standards. It is wrong to assume, for example, that Indian and American regulations on water purity should necessarily be the same. Indians may not be able to afford American water safety standards, just as they unfortunately cannot afford many other goods that Americans can.

Id.

290. See supra Part III(D).

291. See Duffy, supra note 284, at 704. Regarding the TRIPS Agreement's flexibility it has been said:

[Skepticism exists] that there will always be a 'best' rule for every problem that will arise under the TRIPS Agreement. Promoting innovation requires that care be taken not to raise the cost of knowledge to so high a level that 
the value of local diversity. ${ }^{292}$ An example showing the validity of jurisdictional variation exists when considering applying rules from highly-developed countries in the less-developed world. ${ }^{293}$ This uniformity could be considered inappropriate because the widest divergence of preferences might well be found between developed and less-developed countries. ${ }^{294}$

However, there are two significant limitations to the local preferences argument. ${ }^{295}$ First, harmonized patent law does not result in the same degree of uniformity as other harmonized laws, e.g., wage law. ${ }^{296}$ Second, and more importantly, the local preferences argument is less compelling where the diversity occurs between nations having similar preferences than where preferences are likely to be widely divergent. ${ }^{297}$ However, the case for jurisdictional variation does not rest solely on matching local preferences. ${ }^{298}$

Another justification for permitting jurisdictional variation is that tolerating variation will breed jurisdictional competition, in turn, checking governmental inefficiency and abuse. ${ }^{299}$ However, this argument does not

it impedes further inventiveness. How that problem is best solved can depend on a country's intellectual and industrial development, its culture, and the types of creative work in which its citizens are engaged. Thus, the nature (and advantage) of a minimum standards regime is that where there is no best rule that will work in every economy, each country can tailor the law to its own needs.

Id.

292. See id. "Its very first article guarantees that "Members shall be free to determine the appropriate method of implementing the provisions of this Agreement within their own legal system and practice." Id. at 705. "Similarly, Article 27 , which generally mandates that patents shall be available in all fields of technologies, allows countries to create exceptions from patentability 'necessary to protect ordre public or morality' - a standard understood to 'depend to a certain degree on the particular culture of a country or region." Id.; see TRIPS, supra note 55, art. 27. "Consistent with theory, the TRIPS Preamble explicitly recognizes 'the special needs of the least-developed country Members in respect of maximum flexibility in the domestic implementation of laws and regulations in order to enable them to create a sound and viable technological base." Duffy, supra note 284 , at 705 . "Special provision is also made for countries and nations 'in the process of transformation from a centrally-planned into a market, free-enterprise economy,' both of which are likely to have preferences that widely diverge from those in developed, free-market nations." Id.

293. See Duffy, supra note 284 , at 705.

294. See id.

295. See id. at 706.

296. See id. "The patent right does not mandate any particular price for an innovation. Patentees are free to sell their inventions and license their rights on different terms in different areas." Id. "In fact, the available evidence demonstrates that patentees often do engage in price discrimination - for example, by lowering the prices of patented drugs in poorer countries." Id.

297. See Duffy, supra note 284, at 706 . "If local preferences were the sole reason for maintaining legal diversity, a general harmonization of law among similarly situated nations, e.g., among developed nations, might be desirable." $l d$.

298. See id.

299. See id. "This is sometimes referred to as the 'Leviathan' argument because the competition checks otherwise harmful tendencies of monopolistic governmental power." Id. at 707 . 
present very powerful reasons for resisting global patent harmonization because even where harmonization is pursued in a number of legal issues, competition on other points can still provide an effective check on government. ${ }^{300}$ Also, patent law presents this argument with a problem because the variation now existing among nations' patent law is not imposing any significant check on government inefficiency. ${ }^{301}$

Jurisdictional variation may also allow legal innovation to occur more rapidly. ${ }^{302} \mathrm{~A}$ legal innovation can be valuable not only to the jurisdiction of the innovation, but to others based upon information produced by the results of the innovation. ${ }^{303}$ This innovation rationale has other implications apart from the others reasons supporting jurisdictional variation. ${ }^{304}$ The innovation rationale is different than a rationale based on matching local preferences because any innovations in patent law are probably more likely to occur in developed nations, which already possess a sophisticated understanding of the area. ${ }^{305}$ Innovations are less likely in less-developed nations, which do not have long experience with patent systems. ${ }^{306}$ Because an experimentation rationale gives reason to tolerating diversity between developed nations, it may be sensible to tolerate more diversity between developed nations than between developed and less-developed nations. ${ }^{307}$ However, even if only the developed countries

300. See id. "The point here is familiar to regulated industries scholars: Even where regulation constrains competition along one axis (e.g., by fixing price), firms can still compete with each other along other axes (e.g., by improving quality)." See Duffy, supra note 284, at 707. "Thus, harmonizing law in one particular area (e.g., IP) would leave jurisdictions free to compete for capital and, to a lesser extent, labor, through jurisdictional differences in other areas of law (e.g., tax policy, environmental standards, etc.)." Id. at 707.

301. See id. "With few exceptions, the government of each nation still holds a monopoly on the power to issue patents within its borders, and thus government patent offices are not subject to any significant competition under the current state of affairs." Id. "To the extent that a patent office has incentives to be lazy or abusive, those incentives will not be checked by competition from other jurisdictions." Id. "Therefore, consolidation of national offices into a single world patent office would not necessarily have any significant costs in terms of sacrificing competitive checks on bureaucrats." Id.

302. See Duffy, supra note 284 , at 707 . The point was made famous by Justice Brandeis, who observed that "it is one of the happy incidents of the federal system that a single courageous state may, if its citizens choose, serve as a laboratory, and try novel social and economic experiments without risk to the rest of the country." Id. at 708; see also New State Ice Co. v. Liebmann, 285 U.S. 262,311 (1932) (Brandeis, J., dissenting).

303. See Duffy, supra note 284 , at 707.

304. See id. at 708. "It provides a more substantial basis to oppose patent harmonization than does the Leviathan argument because, as previously explained, enforcing uniformity in one area of law may still permit significant legal competition to check government inefficiency." Id. "But any degree of harmonization necessarily removes the harmonized point from parallel experimentation by different jurisdictions and is thus likely to significantly retard further development as to that aspect of the law." Id.

305. See id.

306. See id. "It may also be unwise for less-developed nations to undertake risky experiments with their embryonic patent systems, which may not be able to weather a failure." Duffy, supra note 284 , at 708 .

307. See id. 
are able to experiment through legal innovation, the history of patent law has shown that even experimentation conducted by large nation-states can produce significant new ideas in law. ${ }^{308}$

\section{CONCLUSION}

It is obvious many obstacles need to be overcome before a globally harmonized patent system is put into place. The United States will play a large part in this, because, in order for there to be one global patent system, it likely needs to convert to the first-to-file system, ${ }^{309}$ used in the rest of the world. Recently the head of the U.S. Patent Office stated that he was prepared to reconsider the first-to-invent principle in the interest of securing a harmonized global system that would make it easier and cheaper for inventors to obtain patent protection worldwide. ${ }^{310}$ This would be a major step in the quest for patent harmonization. It is unlikely that this step alone would transform the current state of international patent law into that of one unified system such as the WPS ${ }^{311}$ discussed earlier.

Developing countries will need to agree to harmonization laws as well, as these countries develop and become bigger contributors to the world's technology. It may be that a system with jurisdictional variation ${ }^{312}$ would be more suited for smaller countries. If this were the case, it would be impossible for the world to be productive using one unified system.

Whatever the case may be, it is apparent that world has been making strides for more than a century to come to some agreement on common patent law rules. ${ }^{313}$ However, these agreements have only begun the harmonization and have not changed the core principles to which individual nations adhere. To create an even, more uniform system, nations will most likely have to make compromises in how they perceive patent systems functioning. Only when these countries are willing to make these sacrifices will the world possibly see one globally harmonized patent law system.

Randy L. Campbell

308. See id. "The value of jurisdictional diversity in encouraging legal innovation has remained controversial in the literature." Id.

309. See supra Part IV.

310. Frances Williams, U.S. Softens Stance on Patents, FinANCIAL Times (London), Mar. 27, 2002, International Economy section, at 5.

311. See supra Part VI(A).

312. See supra Part VI(B).

313. See supra Part III.

* J.D. Indiana University School of Law - Indianapolis, 2003 (expected); M.S.E.E., Purdue University 2000; B.S.E.E., Purdue University, 1997. 